\title{
Predictors of long-term smoking cessation: results from the global adult tobacco survey in Poland (2009-2010)
}

Dorota Kaleta ${ }^{* *}$, Przemysław Korytkowski ${ }^{2}$, Teresa Makowiec-Dąbrowska ${ }^{3,4}$, Bukola Usidame ${ }^{5}$, Leokadia Bąk-Romaniszyn ${ }^{6}$ and Adam Fronczak ${ }^{7}$

\begin{abstract}
Background: Expanding the information on determinants of smoking cessation is crucial for developing and implementing more effective tobacco control measures at the national as well as European levels. Data on smoking cessation and its social correlates among adults from middle-income countries of Central and Eastern Europe are still poorly reported in the literature. The aim of the study was to analyze the association of socio-demographic indicators with long term tobacco smoking cessation (quit smoking for at least one year prior to interview) among adults. Moreover, we evaluated motives for giving up smoking from former smokers.
\end{abstract}

Methods: Data on former as well as current smokers' socio-demographic and smoking-related characteristics were derived from the Global Adult Tobacco Survey (GATS). GATS is a cross-sectional, nationally representative household survey implemented in Poland between 2009 and 2010. GATS collected data on a representative sample of 7,840 individuals including 1,206 individuals who met the criteria of long-term smoking cessation and 2,233 current smokers. Smoking cessation rate was calculated as the number of former smokers divided by the number of ever smokers. Logistic regression analyses were used to obtain odds ratios (ORs) and 95\% confidence interval (Cl) of the broad number of variables on successful cessation of smoking.

Results: Among females the quit rate was 30.4\% compared to 37.9\% in males ( $p<0.01)$. Former smokers declared concerns about the health hazard of smoking (60.8\%) and the high price of cigarettes (11.6\%) as primary reasons for smoking cessation. Older age, high education attainment, awareness of smoking health consequences was associated with long-term quitting among both genders. Also employed males had over twice the probability of giving up smoking compared with unemployed, and being religious did not contribute to successful smoking cessation.

Conclusion: Results indicated that smoking cessation policies focused on younger age groups are vital for curbing tobacco epidemic in Poland and should become a public health main concern. There is also the need for interventions to raise awareness on smoking health risks and quitting benefits are crucial to increase cessation potential among adult smokers. Nevertheless further effort needs to be done to prevent smoking uptake.

Keywords: Tobacco smoking cessation, Socio-demographic factors, Adults, GATS, Poland

\footnotetext{
* Correspondence: dkaleta@op.pl

'Department of Preventive Medicine, Medical University of Łódź, Łódź, Poland

Full list of author information is available at the end of the article
}

\section{Biomed Central}

(c) 2012 Kaleta et al.; licensee BioMed Central Ltd. This is an Open Access article distributed under the terms of the Creative Commons Attribution License (http://creativecommons.org/licenses/by/2.0), which permits unrestricted use, distribution, and reproduction in any medium, provided the original work is properly cited. 


\section{Background}

The most recent report launched by the World Health Organization in 2012 indicated that the burden of deaths attributable to tobacco use is still very high in Europe [1]. The death rate from non-communicable diseases (NCDs-1527 per 100,000 population) was about 21.9 times that for communicable diseases (70 per 100,000 population). Tobacco was responsible for $18 \%$ of all NCDs. Within the NCDs category, ischemic heart disease accounted for 437 deaths per 100,000 population aged 30 years and above, with 16\% these deaths attributed to tobacco. Cancer of the trachea, bronchus and lungs accounted for 71 deaths per 100,000 population with $85 \%$ of these deaths attributable to tobacco. The death rate due to tobacco related diseases in men was 467 per 100,000 men at age 30 years and more, compared with women, 117 per 100,000 women at age 30 years and more. The proportion of deaths attributable to tobacco was close to $25 \%$ in men and $7 \%$ in women. Unfortunately, in Poland these indicators are even higher and the data is alarming [1].

In Poland, tobacco was responsible for $23 \%$ of all NCDs, 90\% of trachea, bronchus and lung cancer. The proportion of deaths attributable to tobacco was close to $31 \%$ in men and $12 \%$ among women aged 30 years and more [1]. The most important aspect is that smoking related deaths are potentially avoidable. Smoking cessation has significant health benefits for smokers at all ages [2]. Increasing the cessation rate is considered the only strategy that can determine a significant reduction in smoking-related mortality among adults in the short term [3]. Interventions that can increase the smoking cessation rate on the population level could save many lives [4].

During the past 30 years, high numbers of smokers in the developed countries have given up tobacco smoking [5]. According to the World Health Organization data, in the 1980s the smoking prevalence in Poland was the highest in the country's history and one of the highest in Europe, including Central and Eastern Europe [6]. In 1982, the percentage of smokers among young and middle-aged men was $70 \%$, and $50 \%$ in a similar-age group of women. Among men, the fall in ratio of daily smokers occurred in all age groups from around 60\% in 1982 to $40 \%$ in $2000-2004$, reaching approximately $1 \%$ rate of annual decline among all men [6]. Among women, the highest decline in incidence of daily smoking occurred in the youngest age group (20-29 years) from $50 \%$ to $25 \%$. Unfortunately, there is evidence in recent years of a slowdown in the rate of decline in smoking prevalence among men, and of a halt in the falling trend among young adult women [6]. Therefore, there is a need to increase the effectiveness of tobacco control measures. Obtaining information on predictors of successful cessation can contribute significantly to improving tobacco control activities on an individual and population level.

Studies that have investigated determinants of tobacco quitting are not homogeneous in terms of methodological approach $[7,8]$. They range in design from cross-sectional, follow-up studies to intervention trials [3,9-12]. Many of these approaches are limited to constricted subgroups [13]. Often surveys have been conducted in populations at high risk of heart disease or cancer patients, and they have a limited range of variation on such variables as age, race, and socioeconomic status [14-20].

Still, little attention is paid to the demographic and social correlates of successful smoking cessation among adult Poles in our country. Evidently more research is needed to update evidence-based data to develop welltargeted tobacco control activities.

The aim of this study was to analyze the association of socio-demographic indicators with the long term tobacco smoking cessation among adults in Poland. Moreover, we assessed the motivations for quitting smoking cigarettes among former smokers.

\section{Methods}

Data on former and current smokers' socio-demographics, as well as smoking-related characteristics, and reasons for smoking cessation were derived from the Global Adult Tobacco Survey (GATS) which was described in detail elsewhere [21]. Global Adult Tobacco Survey is a cross-sectional, nationally representative household survey [22]. The target population was non-institutional residents aged 15 years and older in all 16 voivodeships of Poland [23]. The GATS Poland sample was selected in three stages, where statistical regions were treated as Primary Sampling Units (PSUs). In the first stage of sample selection a total of 200 urban PSUs and 200 rural PSUs were selected with probability proportionate to size according the GATS sample selection requirements.

In the second stage of sample selection 36 households were selected from each urban PSU and 34 households were selected from each rural PSU using simple random sampling without replacement from the National Official Territorial Division Register (TERYT). One individual (eligible man or woman) from each of the participating households were randomly selected. A total of 6800 households were selected (3600 male and 3200 female) from rural PSUs with 7200 households (3800 male and 3400 female) drawn from urban PSUs resulting into a total sample of 14000 non-institutionalized households from all 16 voivodeships for GATS Poland. GATS collected data from 7,840 sampled individuals. GATS data 
were collected by trained pollsters during the face to face interviews between 2009 and 2010.

Data used for the study is publicly available from the website of the Global Tobacco Surveillance System (GTSS). GTSS is a Web-based data application that houses and displays data from four tobacco-related surveys conducted around the world. The purpose of GTSS is to enhance countries' capacity to monitor tobacco use, guide national tobacco prevention, and control programs, and facilitate comparison of tobacco-related data at the national, regional, and global levels.

\section{Questionnaire}

The GATS questionnaire covered socio-demographic issues, detailed demands on current smoking and smoking history [24]. It includes questions on the date smokers began cigarette smoking on a daily basis or the number of years since quitting for ex-smokers. Moreover, the questionnaire determined if the respondent went to a doctor or health care provider in the past 12 months, and whether a respondent was advised by a doctor or health care provider (during any visit in the past 12 months) to quit smoking tobacco. GATS allows to determine whether those who attempted to quit used any of the following aid "counseling by a specialist even at a smoking cessation clinic; used nicotine replacement therapy, e.g. chewing gum, patches, tablets, inhaler and other agents containing nicotine or other prescription drugs, e.g. Tabex, Zyban, Champix; other pharmaceutical agents, quit line advice/helpline, or switching to smokeless tobacco" during the last 12 months. Furthermore GATS questionnaire provided information on the primary reason for quitting smoking cigarettes of respondents [24].

\section{Study variables}

The category for ever smokers covered current and exsmokers subgroups. A current smoker was defined as someone who had smoked more than an average of one cigarette per day on a regular basis for at least one year. A former smoker was defined as someone who had given up smoking for at least one year prior to the interview, capturing our definition of successful smoking cessation [25]. Those respondents who had given up smoking more recently were considered current smokers. Following the analysis previously performed by Kabat et al. overall stopping rates or "quit rates" [rates between ex- and ever-smokers] were calculated for smokers with different characteristics, as the number of former smokers divided by the number of ever smokers and multiplied by $100 \%$ [7]. Data on gender and age of the respondents were also included in our analysis in addition to information on age at smoking onset. Age at smoking onset was characterized as the age at which respondents started to smoke tobacco on a regular basis $(\leq 17,18-20,21$ years or over). We also used in our analysis the data on educational attainment of all subjects. Educational level was regarded as: primary education, vocational education, secondary education, and higher education.

The measure of economic activity classified subjects currently with permanent job as employed, currently with no permanent job as unemployed, and pupils, students, persons occupied with household keeping, retired, pensioners due to disability as economically non-active. Furthermore, respondents were asked whether their place of residence was a rural or urban area (urban area up to 50 000, from 50000 to 200000 , and over 200000 inhabitants). We also took into consideration the awareness of the negative health consequences of smoking. We categorized our respondents as aware (those who answered "yes" to the question: Do you think that tobacco smoking causes serious diseases?) and not aware (those who answered "no" and "do not know"). We also split our subjects according to being religious or not. Moreover, people who declared to be religious were categorized as a: believer practicing regularly; believer but not practicing regularly; believer but not practicing. Reasons stated for quitting smoking cigarettes by respondents were recorded in five categories: cigarettes became too expensive for them, they realized that smoking harms, someone they know decided to quit, now there are less public places where they can smoke, or some other reason.

\section{Statistical analyses}

Statistical associations of the given categories of characteristics in the analyzed groups were assessed with the chi-square test. All analyses were performed separately for men and women in six age groups: under 25, 25-29, $30-39,40-49,50-59,60$ years and older. For the comparison of proportions, a chi-square test was used. We used univariate and multivariate logistic regression analyses of unweighted data to obtain odds ratios (ORs) and 95\% confidence interval (CI) of each indicator on smoking cessation. In the first stage crude coefficients odds ratios (OR) of the impact of odd variables on the successful smoking cessation in males and females were calculated. This was followed by a multifactorial analysis considering the simultaneous effect of all variables on the possibility of successful smoking cessation. All $p$ values were two-sided and $\mathrm{p}<0.05$ was used to denote statistical significance. The STATISTICA Windows XP version 8.0 program was used to perform the statistical analysis.

\section{Results}

Among the 14000 households selected for the survey, 8948 (63.9\%) households and 7840 (93.9\%) sampled 
Table 1 Characteristics of former, current, ever smokers and quit rates by gender - Global Adult Tobacco Survey Poland 2009-2010

\begin{tabular}{|c|c|c|c|c|c|c|c|c|}
\hline \multirow[t]{3}{*}{ Characteristic } & \multicolumn{4}{|l|}{$\begin{array}{l}\text { Male } \\
N=2141\end{array}$} & \multicolumn{4}{|l|}{$\begin{array}{l}\text { Female } \\
\mathrm{N}=1298\end{array}$} \\
\hline & \multirow{2}{*}{$\begin{array}{l}\begin{array}{l}\text { Former } \\
\text { smokers } \mathrm{N}= \\
811\end{array} \\
\mathrm{n}(\%)\end{array}$} & \multirow{2}{*}{$\begin{array}{l}\text { Current } \\
\text { smokers } N= \\
1330 \\
\mathrm{n}(\%)\end{array}$} & \multirow{2}{*}{$\begin{array}{l}\text { Ever smokers } \\
\mathrm{N}=2141 \\
\mathrm{n}(\%)\end{array}$} & \multirow[t]{2}{*}{$\begin{array}{l}\text { Quit } \\
\text { rate\# } \\
\%\end{array}$} & \multirow{2}{*}{$\begin{array}{l}\begin{array}{l}\text { Former } \\
\text { smokers } \mathrm{N}= \\
395\end{array} \\
\mathrm{n}(\%)\end{array}$} & \multirow{2}{*}{$\begin{array}{l}\text { Current } \\
\text { smokers } N= \\
903 \\
\mathrm{n}(\%)\end{array}$} & \multirow{2}{*}{$\begin{array}{l}\text { Ever smokers } \\
\mathrm{N}=1298 \\
\mathrm{n}(\%)\end{array}$} & \multirow[t]{2}{*}{$\begin{array}{l}\text { Quit } \\
\text { rate } \\
\%\end{array}$} \\
\hline & & & & & & & & \\
\hline \multicolumn{9}{|l|}{ Age (years) } \\
\hline$<25$ & $13(1.6)$ & $117(8.8)$ & $130(6.1)$ & 10.0 & $11(2.8)$ & $72(8.0)$ & $83(6.4)$ & 13.3 \\
\hline $25-29$ & $32(3.9)$ & $147(11.1)$ & $179(8.4)$ & 17.9 & $31(7.8)$ & $96(10.6)$ & $127(9.8)$ & 24.4 \\
\hline $30-39$ & $93(11.5)$ & $307(23.1)$ & $400(18.7)$ & 23.3 & $75(19.0)$ & $171(18.9)$ & $246(19.0)$ & 30.5 \\
\hline $40-49$ & $137(16.9)$ & $303(22.8)$ & $440(20.6)$ & 31.1 & $62(15.7)$ & $220(24.4)$ & $282(21.7)$ & 22.0 \\
\hline $50-59$ & $168(20.7)$ & $282(21.2)$ & $450(21.0)$ & 37.3 & $98(24.8)$ & $246(27.2)$ & $344(26.5)$ & 28.5 \\
\hline$\geq 60$ & $368(45.4)$ & $174(13.1)$ & $542(25.3)$ & 67.9 & $118(29.9)$ & $98(10.9)$ & $216(16.6)$ & 54.6 \\
\hline \multicolumn{9}{|l|}{ Age at smoking onset } \\
\hline$\leq 17$ & $315(38.8)$ & $548(41.2)$ & $863(40.3)$ & 36.5 & $95(24.1)$ & $262(29.0)$ & $357(27.5)$ & 26.6 \\
\hline $18-20$ & $362(44.6)$ & $551(41.4)$ & $913(42.6)$ & 39.6 & $194(49.1)$ & $400(44.3)$ & $594(45.8)$ & 32.7 \\
\hline$\geq 21$ & $134(16.5)$ & $231(17.4)$ & $365(17.0)$ & 36.7 & $106(26.8)$ & $241(26.7)$ & $347(26.7)$ & 30.5 \\
\hline \multicolumn{9}{|l|}{ Education } \\
\hline primary & $202(24.9)$ & $203(15.3)$ & $405(18.9)$ & 49.9 & $55(13.9)$ & $112(12.4)$ & $167(12.9)$ & 32.9 \\
\hline vocational & $264(32.6)$ & $584(43.9)$ & $848(39.6)$ & 31.1 & $100(25.3)$ & $257(28.5)$ & $357(27.5)$ & 28.0 \\
\hline secondary & $257(31.7)$ & $428(32.2)$ & $685(32.0)$ & 37.5 & $163(41.3)$ & $399(44.2)$ & $562(43.3)$ & 29.0 \\
\hline high & $88(10.9)$ & $115(8.6)$ & $203(9.5)$ & 43.3 & $77(19.5)$ & $135(15.0)$ & $212(16.3)$ & 36.3 \\
\hline \multicolumn{9}{|l|}{ Occupational classification } \\
\hline non-economically active & $425(52.4)$ & $327(24.6)$ & $752(35.1)$ & 56.5 & $217(54.9)$ & $355(39.3)$ & $572(44.1)$ & 37.9 \\
\hline employed & $355(43.8)$ & $864(65.0)$ & $1219(56.9)$ & 29.1 & $155(39.2)$ & $488(54.0)$ & $643(49.5)$ & 24.1 \\
\hline $\begin{array}{l}\text { unemployed. currently } \\
\text { with no permanent job }\end{array}$ & $27(3.3)$ & $137(10.3)$ & $164(7.7)$ & 16.5 & $22(5.6)$ & $59(6.5)$ & $81(6.2)$ & 27.2 \\
\hline \multicolumn{9}{|l|}{ Place of residence } \\
\hline rural & $456(56.2)$ & $690(51.9)$ & 1146 (53.5) & 39.8 & $169(42.8)$ & $364(40.3)$ & $533(41.1)$ & 31.7 \\
\hline \multicolumn{9}{|l|}{ urban } \\
\hline up to 50000 & 151 (18.6) & 234 (17.6) & 385 (18.0) & 39.2 & $83(21.0)$ & $158(17.5)$ & 241 (18.6) & 34.4 \\
\hline $50000-200000$ & $80(9.9)$ & $176(13.2)$ & $256(12.0)$ & 31.3 & $63(15.9)$ & $163(18.1)$ & $226(17.4)$ & 27.9 \\
\hline over 200000 & $124(15.3)$ & $230(17.3)$ & 354 (16.5) & 35.0 & $80(20.3)$ & $218(24.1)$ & $298(23.0)$ & 26.8 \\
\hline \multicolumn{9}{|l|}{ Religiosity } \\
\hline $\begin{array}{l}\text { believer practicing } \\
\text { regularly }\end{array}$ & $441(54.4)$ & $483(36.3)$ & $924(43.2)$ & 47.7 & $198(50.1)$ & $327(36.2)$ & $525(40.4)$ & 37.7 \\
\hline $\begin{array}{l}\text { believer but practicing } \\
\text { not regularly }\end{array}$ & $220(27.1)$ & 481 (36.2) & 701 (32.7) & 31.4 & $127(32.2)$ & $364(40.3)$ & 491 (37.8) & 25.9 \\
\hline $\begin{array}{l}\text { believer but } \\
\text { not practicing }\end{array}$ & $98(12.1)$ & $287(21.6)$ & 385 (18.0) & 25.5 & $50(12.7)$ & $160(17.7)$ & $210(16.2)$ & 23.8 \\
\hline not religious & $28(3.5)$ & $53(4.0)$ & $81(3.8)$ & 34.6 & $8(2.0)$ & $28(3.1)$ & $36(2.8)$ & 22.2 \\
\hline \multicolumn{9}{|c|}{ Awareness of smoking health consequences } \\
\hline yes & $774(95.4)$ & $1081(81.3)$ & 1855 (86.6) & 41.7 & $374(94.7)$ & $742(82.2)$ & $1116(86.0)$ & 33.5 \\
\hline no & $14(1.7)$ & $160(12.0)$ & $174(8.1)$ & 8.0 & $8(2.0)$ & $78(8.6)$ & $86(6.6)$ & 9.3 \\
\hline
\end{tabular}

\#Quit rates = no. former smokers/no. ever smokers $\mathrm{x} 100$.

persons successfully completed the interviews. The overall survey participation rate was $65.1 \%$. Of the 7840 respondents, 1206 subjects (811 men and 395 women) had quit smoking and did not smoke for at least 1 year before the interview. Current smokers were 1330 male and 903 female. Distribution of former, current, and ever smokers and quit rates of the study sample by gender and selected characteristics are available in Table 1. 
Table 2 Reasons to quit among former smokers by gender and selected characteristics - Global Adult Tobacco Survey Poland 2009-2010

\begin{tabular}{|c|c|c|c|c|c|c|c|c|c|c|}
\hline \multirow[t]{3}{*}{ Characteristic } & \multicolumn{5}{|l|}{$\begin{array}{l}\text { Male } \\
\mathrm{N}=795\end{array}$} & \multicolumn{5}{|l|}{$\begin{array}{l}\text { Female } \\
\mathrm{N}=387\end{array}$} \\
\hline & $\begin{array}{l}\text { cigarettes } \\
\text { became too } \\
\text { expensive } N= \\
100\end{array}$ & $\begin{array}{l}\text { realized } \\
\text { smoking is } \\
\text { harmful } N= \\
533\end{array}$ & $\begin{array}{l}\text { someone } \\
\text { decided to } \\
\text { quit } N=32\end{array}$ & $\begin{array}{l}\text { less } \\
\text { public } \\
\text { places } \\
N=1\end{array}$ & $\begin{array}{l}\text { Other } \\
N= \\
129\end{array}$ & $\begin{array}{l}\text { cigarettes } \\
\text { became too } \\
\text { expensive } \mathrm{N} \\
=40\end{array}$ & $\begin{array}{l}\text { realized } \\
\text { smoking is } \\
\text { harmful } N= \\
200\end{array}$ & $\begin{array}{l}\text { someone } \\
\text { decided to } \\
\text { quit } N=25\end{array}$ & $\begin{array}{l}\text { less } \\
\text { public } \\
\text { places } \\
N=1\end{array}$ & $\begin{array}{l}\text { Other } \\
N= \\
121\end{array}$ \\
\hline & n (\%) & n (\%) & n (\%) & n (\%) & n (\%) & n (\%) & n (\%) & n (\%) & n (\%) & n (\%) \\
\hline \multicolumn{11}{|l|}{ Age (years) } \\
\hline$<25$ & $3(23.1)$ & $8(61.5)$ & $0(0.0)$ & $0(0.0)$ & $\begin{array}{l}2 \\
(15.4)\end{array}$ & $3(27.3)$ & $4(36.4)$ & $0(0.0)$ & $0(0.0)$ & $\begin{array}{l}4 \\
(36.4)\end{array}$ \\
\hline $25-29$ & $6(19.4)$ & $17(54.8)$ & $0(0.0)$ & $0(0.0)$ & $\begin{array}{l}8 \\
(25.8) \\
\end{array}$ & $4(12.9)$ & $14(45.2)$ & $1(3.2)$ & $0(0.0)$ & $\begin{array}{l}12 \\
(38.7) \\
\end{array}$ \\
\hline $30-39$ & $13(14.3)$ & $59(64.8)$ & $5(5.5)$ & $0(0.0)$ & $\begin{array}{l}14 \\
(15.4) \\
\end{array}$ & $3(4.2)$ & $40(55.6)$ & $3(4.2)$ & $0(0.0)$ & $\begin{array}{l}26 \\
(36.1) \\
\end{array}$ \\
\hline $40-49$ & $22(16.5)$ & $91(68.4)$ & $2(1.5)$ & $0(0.0)$ & $\begin{array}{l}18 \\
(13.5) \\
\end{array}$ & $5(8.1)$ & $33(53.2)$ & $9(14.5)$ & $1(1.6)$ & $\begin{array}{l}14 \\
(22.6) \\
\end{array}$ \\
\hline $50-59$ & $21(12.7)$ & $109(66.1)$ & $9(5.5)$ & $0(0.0)$ & $\begin{array}{l}26 \\
(15.8)\end{array}$ & $13(13.4)$ & $45(46.4)$ & $5(5.2)$ & $0(0.0)$ & $\begin{array}{l}34 \\
(35.1)\end{array}$ \\
\hline$\geq 60$ & $35(9.7)^{a}$ & $249(68.8)$ & $16(4.4)$ & $1(0.3)$ & $\begin{array}{l}61 \\
(16.9)\end{array}$ & $12(10.5)$ & $64(56.1)$ & $7(6.1)$ & $0(0.0)$ & $\begin{array}{l}31 \\
(27.2)\end{array}$ \\
\hline \multicolumn{11}{|l|}{ Education } \\
\hline primary & $24(12.2)$ & $132(67.3)$ & $11(5.6)$ & $0(0.0)$ & $\begin{array}{l}29 \\
(14.8)\end{array}$ & $6(11.3)$ & $29(54.7)$ & $2(3.8)$ & $0(0.0)$ & $\begin{array}{l}16 \\
(30.2)\end{array}$ \\
\hline vocational & $39(14.9)$ & $180(68.7)$ & $10(3.8)$ & $0(0.0)$ & $\begin{array}{l}33 \\
(12.6)\end{array}$ & 15 (15.6) & $50(52.1)$ & $5(5.2)$ & $0(0.0)$ & $\begin{array}{l}26 \\
(27.1)\end{array}$ \\
\hline secondary & $33(13.1)$ & $168(66.9)$ & $5(2.0)^{c}$ & $0(0.0)$ & $\begin{array}{l}45 \\
(17.9)\end{array}$ & $16(9.9)$ & 77 (47.8) & $12(7.5)$ & $0(0.0)$ & $\begin{array}{l}56 \\
(34.8)\end{array}$ \\
\hline high & $4(4.7)^{b}$ & $53(61.6)$ & $6(7.0)^{d}$ & $1(1.2)$ & $\begin{array}{l}22 \\
(25.6) \\
e, f\end{array}$ & $3(3.9)^{9}$ & $44(57.1)$ & $6(7.8)$ & $1(1.3)$ & $\begin{array}{l}23 \\
(29.9)\end{array}$ \\
\hline
\end{tabular}

\section{Occupational classification}

\begin{tabular}{|c|c|c|c|c|c|c|c|c|c|c|}
\hline $\begin{array}{l}\text { non- } \\
\text { economically } \\
\text { active }\end{array}$ & $42(9.8)$ & 199 (46.5) & $134(31.3)$ & $0(0.0)$ & $\begin{array}{l}53 \\
(12.4)\end{array}$ & $14(9.8)$ & $76(53.1)$ & $12(8.4)$ & $1(0.7)$ & $\begin{array}{l}40 \\
(28.0)\end{array}$ \\
\hline employed & 49 (14.2) & $226(65.3)^{j}$ & $14(4.0)^{\prime}$ & $0(0.0)$ & $\begin{array}{l}57 \\
(16.5)\end{array}$ & $17(11.1)$ & $80(52.3)$ & $12(7.8)$ & $1(0.7)$ & $\begin{array}{l}43 \\
(28.1)\end{array}$ \\
\hline unemployed & $8(29.6)^{h, i}$ & $10(37.0)^{k}$ & $0(0.0)^{m}$ & $0(0.0)$ & $\begin{array}{l}9 \\
(33.3) \\
n, 0\end{array}$ & $2(9.5)$ & $10(47.6)$ & $1(4.8)$ & $0(0.0)$ & $\begin{array}{l}8 \\
(38.1)\end{array}$ \\
\hline
\end{tabular}

Place of residence

\begin{tabular}{|c|c|c|c|c|c|c|c|c|c|c|}
\hline rural & $60(13.5)$ & $300(67.4)$ & $20(4.5)$ & $0(0.0)$ & $\begin{array}{l}65 \\
(14.6) \\
\end{array}$ & $21(12.8)$ & 85 (51.8) & $10(6.1)$ & $0(0.0)$ & $\begin{array}{l}48 \\
(29.3) \\
\end{array}$ \\
\hline \multicolumn{11}{|l|}{ urban } \\
\hline up to 50000 & $18(12.2)$ & 99 (67.3) & $4(2.7)$ & $1(0.7)$ & $\begin{array}{l}25 \\
(17.0)\end{array}$ & $8(9.6)$ & $35(42.2)$ & $6(7.2)$ & $1(1.2)$ & $\begin{array}{l}33 \\
(39.8)\end{array}$ \\
\hline $\begin{array}{l}50000- \\
200000\end{array}$ & $10(12.5)$ & 49 (61.3) & $4(5.0)$ & $0(0.0)$ & $\begin{array}{l}17 \\
(21.3)^{\mathrm{p}}\end{array}$ & $7(11.7)$ & $32(53.3)$ & $2(3.3)$ & $0(0.0)$ & $\begin{array}{l}19 \\
(31.7)\end{array}$ \\
\hline over 200000 & $12(9.8)$ & 85 (69.1) & $4(3.3)$ & $0(0.0)$ & $\begin{array}{l}22 \\
(17.9)\end{array}$ & $4(5.0)$ & $48(60.0)^{r}$ & $7(8.8)$ & $0(0.0)$ & $\begin{array}{l}21 \\
(26.3)\end{array}$ \\
\hline
\end{tabular}

${ }^{a} p<0,04$ age $\geq 60$ vs age $40-49 ;{ }^{b} p<0,03$ high education vs vocational; ${ }^{c} p<0,05$ secondary education vs primary; ${ }^{d} p<0,03$ high education vs secondary; $\mathrm{e}<0,04$ high education vs primary.

${ }^{\mathrm{f}} \mathrm{p}<0,005$ high education vs vocational; ${ }^{\mathrm{g}} \mathrm{p}<0,03$ high education vs vocational; ${ }^{\mathrm{h}} \mathrm{p}<0,04$ unemployed currently with no permanent job vs employed; ${ }^{i} \mathrm{p}<0,02$ unemployed currently with no permanent job vs non-economically active; ${ }^{j} \mathrm{p}<0,001$ employed vs non-economically active; ${ }^{k} \mathrm{p}<0,004$ unemployed currently with no permanent job vs employed; ${ }^{\prime} p<0,001$ employed vs non-economically active ${ }^{m} p<0,001$ unemployed currently with no permanent job vs non-economically active; ${ }^{n} p<0,003$ unemployed currently with no permanent job vs non-economically active.

${ }^{\circ} p<0,03$ unemployed currently with no permanent job vs employed; ${ }^{p} p<0,04$ place of residence urban 50 thous.-200 thous vs rural; ${ }^{r} p<0,03$ place of residence urban over 200 thous vs urban up to 50 thous. 
The mean age of ever-smokers was $48.0 \pm 16.0$ years in men compared to $45.8 \pm 14.1$ years in women $(\mathrm{p}<0.01)$. In the group of current male smokers mean age was $43.0 \pm 14.0$ vs. $43.8 \pm 13.1$ years in female, respectively $(\mathrm{p}>0.05)$. The mean age of former smokers was $56.2 \pm$ 15.6 years in males and $50.3 \pm 15.5$ years in females $(\mathrm{p}<0.001)$.

Women started smoking at a later age than men (data not presented in the tables). While the mean age when smoking began was $18.4 \pm 3.7$ and $18.3 \pm 3.6$ years in former and current male smokers respectively, it was $20.0 \pm 4.4$ (men vs. women $\mathrm{p}<0.001$ ) and $20.0 \pm 4.6$ years in the former and current female smokers respectively (men vs. women $\mathrm{p}<0.001$ ). Among females the quit rate was $30.4 \%$ compared to $37.9 \%$ in males $(p<0.01)$. In addition, women quit at a younger age than men. The mean age of quitting for male and female former smokers was $41.5 \pm 13.5$ and $38.1 \pm 13.3$ years respectively $(\mathrm{p}<0.001)$. Men had been smoking $23.1 \pm 13.3$ years before quitting. Duration of smoking habit was $18.2 \pm$ 12.2 years in the group of female former smokers (males vs. females $\mathrm{p}<0.001)$. Male former smokers reported $14.7 \pm 11.8$ and females $12.1 \pm 10.0$ years since quitting $(\mathrm{p}<0.001)$. From the group of 1206 former smokers (including 811 men and 395 women) 24 respondents (16 men and 8 women) chose "don't know" answer to the question on reasons for quitting smoking and thus were not considered in further calculations. In the group of male former smokers, primary reasons for quitting smoking were: they realized that smoking harms $(\mathrm{n}=$ $533,67 \%$ ), cigarettes became too expensive for them (n $=100,12.6 \%)$, someone they know decided to quit ( $\mathrm{n}=$ $32,4.1 \%)$, now there are less public places where they can smoke $(\mathrm{n}=1, \mathrm{n}=0.1 \%)$, or some other reason $(\mathrm{n}=$ $129,16.2 \%)$. Also in the group of female former smokers, primary reasons for quitting smoking were: they realized that smoking harms $(\mathrm{n}=200,51.7 \%)$, cigarettes became too expensive for them $(n=40,10.3 \%)$, someone they know decided to quit $(\mathrm{n}=25,6.5 \%)$, or some other reason $(\mathrm{n}=121,31.3 \%)$. The detailed distribution of reasons for quitting tobacco smoking among former smokers according to selected socio-demographics is presented in Table 2.

During 12 months prior to the interview 27.0\% ( $\mathrm{n}=$ $359)$ of male current smokers and $29.7 \%(n=268)$ of female current smokers $(p>0.05)$ attempted to give up smoking. In this group only $7.7 \%$ of men and $11.4 \%$ of women $(\mathrm{p}<0.04)$ used professional aid in trying to stop smoking tobacco. In most cases, respondents used pharmacotherapy. Nicotine replacement therapy was the most often used (4.5\% males, 6.6\% females; $\mathrm{p}<0.004)$, and in second place drugs like Tabex or Zyban $(1.2 \%$ males vs. $2.2 \%$ females; $\mathrm{p}>0.05)$. Almost half of the current male smokers - 47.1\% $(\mathrm{n}=528)$ and $39.2 \%(\mathrm{n}=$
297) of the current female smokers had no plans to quit $(\mathrm{p}<0.001)$. Other respondents considered giving up smoking in the future. In the 12 months preceding the survey 1331 (including 173 men and 618 women; p < 0.001 ) current smokers saw a doctor or other health care provider from various reasons. Out of this group, the expert discussed tobacco smoking with $61.5 \%$ men and $59.0 \%$ women $(\mathrm{p}>0.05)$, while $45.9 \%$ men and $43.5 \%$ women were advised to quit smoking ( $\mathrm{p}>0.05)$.

\section{Univariate analysis}

The results of the univariate and multivariate regression analyses are presented in Tables 3 and 4 . In men, the long-term quit rates increased with age. The quit rates were highest among the male subjects of 60 years of age or older compared to those aged 25-29 years $(\mathrm{OR}=$ 19.0; 95\% CI: 10.4-34.7; p < 0.0001). Women who were age 60 years or older had an increased like hood of longterm smoking cessation $(\mathrm{p}<0.0001)$. Successful cessation was associated with education. Male subjects who declared vocational education had lower probabilities of long-term smoking cessation compared with the highly educated ones (men OR $=0.6$; 95\% CI: 0.4-0.8; $\mathrm{p}<0.001$, women $\mathrm{OR}=0.7$; 95\% CI: 0.5-1.0; $\mathrm{p}<0.05)$. Female subjects who had vocational education achieved also a lower quit rate compared to those with higher education $(\mathrm{OR}=$ 0.7; 95\% CI: 0.5-1.0; $\mathrm{p}<0.05)$. Among the male population, the likelihood of quitting successfully was more than 6.5 times higher in the category of non-economically active compared to the unemployed group (OR $=6.6 ; 95 \%$ CI: 4.3-10.21). Also employed males had over twice the probability of giving up smoking compared with unemployed ( $\mathrm{OR}=2.1$; 95\% CI: 1.3-3.2). Employment status was not significantly associated with long-term quitting in women. The residents of urban areas of 50000 to 200000 of inhabitants were less successful in quitting compared to the people living in rural settings $(\mathrm{p}<0.05)$. In men, those who considered themselves religious and practiced regularly were significantly more likely to quit smoking for one year or longer compared to the non-religious ones $(\mathrm{OR}=$ 1.7; 95\% CI: $1.1-2.8 ; \mathrm{p}<0.05)$. On the other hand, place of residence and being a religious person were not significantly associated with long-term quitting in women. Among the male population, the rate of ex-smokers was over eight times higher in the group that considered smoking to cause serious illnesses, compared to the people that did not perceive smoking as dangerous to health $(\mathrm{OR}=8.2 ; 95 \% \mathrm{CI}$ : 4.7-14.2; $\mathrm{p}<0.0001)$. Among women awareness of smoking health consequences contributed to quitting successfully as well $(\mathrm{OR}=4.9 ; 95 \% \mathrm{CI}$ : 2.3-10.3; $\mathrm{p}<0.0001)$. In the univariate analysis, age at smoking onset was not significantly associated with longterm quitting among men. In women age at smoking 
Table 3 Odds Ratios (OR) and 95\% Confidence Intervals (CI) for long-term smoking cessation to selected sociodemographic characteristics in men - Global Adult Tobacco Survey Poland (2009-2010)

\begin{tabular}{|c|c|c|c|c|c|c|}
\hline \multirow[t]{2}{*}{ Variable } & \multirow{2}{*}{$\begin{array}{l}\text { Total } \\
\text { (n) }\end{array}$} & \multirow{2}{*}{$\begin{array}{l}\text { Quit } \\
\text { rate }\end{array}$} & \multicolumn{2}{|c|}{ Univariate logistic regression } & \multicolumn{2}{|c|}{ Multivariate logistic regression $^{a}$} \\
\hline & & & $\overline{O R}$ & $95 \% \mathrm{Cl}$ & $\overline{O R}$ & $95 \% \mathrm{Cl}$ \\
\hline \multicolumn{7}{|l|}{ Age (years) } \\
\hline$<25$ & 130 & 10.0 & 1.00 & reference & 1.00 & reference \\
\hline $25-29$ & 179 & 17.9 & 1.96 & $0.98-3.90$ & 1.94 & $0.95-3.94$ \\
\hline $30-39$ & 400 & 23.3 & $2.73 \mathrm{C}$ & $1.47-5.06$ & $3.05 d$ & $1.60-5.80$ \\
\hline $40-49$ & 440 & 31.1 & $4.07 \mathrm{~d}$ & $2.22-7.47$ & $4.99 \mathrm{~d}$ & $2.65-9.41$ \\
\hline $50-59$ & 450 & 37.3 & $5.36 \mathrm{~d}$ & $2.93-9.81$ & $6.42 d$ & $3.44-11.99$ \\
\hline$\geq 60$ & 542 & 67.9 & $19.03 d$ & $10.44-34.71$ & $19.47 d$ & $10.13-37.43$ \\
\hline \multicolumn{7}{|l|}{ Age at smoking onset } \\
\hline$\leq 17$ & 863 & 26.6 & 1.00 & reference & 1.00 & reference \\
\hline $18-20$ & 913 & 32.7 & 1.14 & $0.94-1.38$ & 0.88 & $0.71-1.11$ \\
\hline$\geq 21$ & 365 & 30.5 & 1.01 & $0.78-1.30$ & 0.58 & $0.42-0.76$ \\
\hline \multicolumn{7}{|l|}{ Education } \\
\hline primary & 405 & 49.9 & 1.30 & $0.93-1.82$ & 0.67 & $0.42-1.06$ \\
\hline vocational & 848 & 31.1 & $0.59 \mathrm{c}$ & $0.43-0.81$ & $0.59 \mathrm{~b}$ & $0.39-0.88$ \\
\hline secondary & 685 & 37.5 & 0.78 & $0.57-1.08$ & 0.93 & $0.62-1.39$ \\
\hline high & 203 & 43.3 & 1.00 & reference & 1.00 & reference \\
\hline \multicolumn{7}{|l|}{ Occupational classification } \\
\hline economically not active & 752 & 56.5 & $6.60 \mathrm{~d}$ & $4.26-10.21$ & $2.10 \mathrm{C}$ & $1.29-3.41$ \\
\hline employed & 1219 & 29.1 & $2.08 \mathrm{~d}$ & $1.35-3.21$ & $1.74 \mathrm{~b}$ & $1.11-2.71$ \\
\hline unemployed & 164 & 16.5 & 1.00 & reference & 1.00 & reference \\
\hline \multicolumn{7}{|l|}{ Place of residence } \\
\hline rural & 1146 & 39.8 & 1.00 & reference & 1.00 & reference \\
\hline \multicolumn{7}{|l|}{ urban } \\
\hline up to 50000 & 385 & 39.2 & 0.99 & $0.77-1.24$ & 1.07 & $0.81-1.40$ \\
\hline $50000-200000$ & 256 & 31.3 & $0.69 \mathrm{~b}$ & $0.51-0.92$ & 0.71 & $0.50-1.00$ \\
\hline over 200000 & 354 & 35.0 & 0.82 & $0.63-1.04$ & 0.97 & $0.72-1.32$ \\
\hline \multicolumn{7}{|l|}{ Religiosity } \\
\hline believer practicing regularly & 924 & 47.7 & $1.73 \mathrm{~b}$ & $1.07-2.78$ & 1.05 & $0.66-1.66$ \\
\hline believer but practicing not regularly & 701 & 31.4 & 0.87 & $0.53-1.41$ & 0.73 & $0.46-1.16$ \\
\hline believer but not practicing & 385 & 25.5 & 0.65 & $0.39-1.08$ & $0.58 \mathrm{~b}$ & $0.36-0.94$ \\
\hline not religious & 81 & 34.6 & 1.00 & reference & 1.00 & reference \\
\hline \multicolumn{7}{|c|}{ Awareness of smoking health consequences } \\
\hline yes & 1855 & 41.7 & $8.18 d$ & $4.70-14.24$ & $5.58 d$ & $3.80-8.15$ \\
\hline no & 174 & 8.0 & 1.00 & reference & 1.00 & reference \\
\hline
\end{tabular}

${ }^{a}$ Fully adjusted model including: age, age at smoking onset, Education,. occupational classification, place of residence, Religiosity, awareness of smoking health consequences.

${ }^{\mathrm{b}} \mathrm{p} \leq 0.05$.

$c p \leq 0.01$.

$\mathrm{d} p \leq 0.001$.

onset was significantly associated with long-term quitting $(\mathrm{OR}=1.7 ; 95 \%$ CI: $1.1-2.8 ; \mathrm{p}<0.05)$.

\section{Multivariate analysis}

Age occurred as a significant, independent predictor of the long-term tobacco quitting among men and women (Tables 3 and 4). The odds of smoking cessation increased with age and were highest for the oldest age group ( $\mathrm{p}<0.0001)$. Moreover, low education attainment was negatively associated with quitting smoking for both genders. The quit rate was lower among men who reported vocational education than among men with higher education $(\mathrm{OR}=0.6 ; 95 \% \mathrm{CI} 0.4-0.9 ; \mathrm{p}<0.05)$. Quitting probability was decreased among women who reported lower educational levels (primary/vocational/ secondary) than among women with higher education 
Table 4 Odds Ratios (OR) and 95\% Confidence Intervals (CI) for long-term smoking cessation to selected sociodemographic characteristics in women - Global Adult Tobacco Survey Poland (2009-2010)

\begin{tabular}{|c|c|c|c|c|c|c|}
\hline \multirow[t]{2}{*}{ Variable } & \multirow{2}{*}{$\begin{array}{l}\text { Total } \\
\text { (n) }\end{array}$} & \multirow{2}{*}{$\begin{array}{l}\text { Quit } \\
\text { rate }\end{array}$} & \multicolumn{2}{|c|}{ Univariate logistic regression } & \multicolumn{2}{|c|}{ Multivariate logistic regression } \\
\hline & & & $\overline{O R}$ & $95 \% \mathrm{Cl}$ & $\overline{O R}$ & $95 \mathrm{Cl}$ \\
\hline \multicolumn{7}{|l|}{ Age (years) } \\
\hline$<25$ & 83 & 13.3 & 1.00 & reference & 1.00 & reference \\
\hline $25-29$ & 127 & 24.4 & 2.11 & $0.99-4.47$ & 2.15 & $0.99-4.66$ \\
\hline $30-39$ & 246 & 30.5 & $2.87 \mathrm{C}$ & $1.44-5.72$ & $3.34 \mathrm{c}$ & $1.63-6.87$ \\
\hline $40-49$ & 282 & 22.0 & 1.84 & $0.92-3.69$ & $2.27 \mathrm{~b}$ & $1.09-4.72$ \\
\hline $50-59$ & 344 & 28.5 & $2.61 \mathrm{c}$ & $1.33-5.13$ & $3.15 c$ & $1.55-6.40$ \\
\hline$\geq 60$ & 216 & 54.6 & $7.88 d$ & $3.96-15.69$ & $8.42 \mathrm{~d}$ & $3.99-17.80$ \\
\hline \multicolumn{7}{|l|}{ Age at smoking onset } \\
\hline$\leq 17$ & 357 & 26.6 & 1.00 & reference & 1.00 & reference \\
\hline $18-20$ & 594 & 32.7 & $1.34 \mathrm{~b}$ & $1.00-1.79$ & 1.04 & $0.76-1.43$ \\
\hline$\geq 21$ & 347 & 30.5 & 1.21 & $0.88-1.68$ & 0.74 & $0.51-1.07$ \\
\hline \multicolumn{7}{|l|}{ Education } \\
\hline primary & 167 & 32.9 & 0.86 & $0.56-1.32$ & $0.52 \mathrm{~b}$ & $0.30-0.92$ \\
\hline vocational & 357 & 28.0 & $0.68 \mathrm{~b}$ & $0.47-0.98$ & $0.55 b$ & $0.34-0.88$ \\
\hline secondary & 562 & 29.0 & 0.72 & $0.51-1.00$ & $0.64 \mathrm{~b}$ & $0.42-0.97$ \\
\hline high & 212 & 36.3 & 1.00 & reference & 1.00 & reference \\
\hline \multicolumn{7}{|l|}{ Occupational classification } \\
\hline economically not active & 572 & 37.9 & 1.64 & $0.98-2.75$ & 1.18 & $0.68-2.05$ \\
\hline employed & 643 & 24.1 & 0.85 & $0.50-1.43$ & 0.79 & $0.46-1.36$ \\
\hline unemployed & 81 & 27.2 & 1.00 & reference & 1.00 & reference \\
\hline \multicolumn{7}{|l|}{ Place of residence } \\
\hline rural & 533 & 31.7 & 1.00 & reference & 1.00 & reference \\
\hline \multicolumn{7}{|l|}{ urban } \\
\hline up to 50000 & 241 & 34.4 & 1.13 & $0.82-1.56$ & 1.11 & $0.78-1.58$ \\
\hline $50000-200000$ & 226 & 27.9 & 0.83 & $0.59-1.17$ & 0.81 & $0.56-1.19$ \\
\hline over 200000 & 298 & 26.8 & 0.79 & $0.58-1.08$ & 0.81 & $0.57-1.16$ \\
\hline \multicolumn{7}{|l|}{ Religiosity } \\
\hline believer practicing regularly & 525 & 37.7 & 2.12 & $0.95-4.74$ & 1.66 & $0.91-3.03$ \\
\hline believer but practicing not regularly & 491 & 25.9 & 1.22 & $0.54-2.75$ & 1.12 & $0.62-2.05$ \\
\hline believer but not practicing & 210 & 23.8 & 1.09 & $0.47-2.55$ & 1.03 & $0.53-1.98$ \\
\hline not religious & 36 & 22.2 & 1.00 & reference & 1.00 & Reference \\
\hline \multicolumn{7}{|c|}{ Awareness of smoking health consequences } \\
\hline yes & 1116 & 33.5 & $4.91 \mathrm{~d}$ & $2.35-10.28$ & $4.39 d$ & $2.69-7.18$ \\
\hline no & 86 & 9.3 & 1.00 & reference & 1.00 & reference \\
\hline
\end{tabular}

${ }^{a}$ Fully adjusted model including: age, age at smoking onset, education, occupational classification, place of residence, Religiosity, awareness of smoking health consequences.

${ }^{\mathrm{b}} \mathrm{p} \leq 0.05$.

${ }^{c} p \leq 0.01$.

$\mathrm{d} p \leq 0.001$.

(primary: $\mathrm{OR}=0.5 ; 95 \% \mathrm{CI} 0.3-0.9$; vocational: $\mathrm{OR}=0.5$; 95\% CI $0.3-0.9$; secondary: $\mathrm{OR}=0.6$; $95 \%$ CI $0.4-1.0$; $\mathrm{p}<0.05)$. Employment status was not associated with cessation likelihood among women, while this association was observed among men. The probability of longterm smoking cessation was over 2 times higher among respondents who were not economically active $(\mathrm{OR}=$ 2.1; 95\% CI: $1.29-3.4 ; \mathrm{p}<0.001$ ), and about 2 times higher for employed men $(\mathrm{OR}=1.7 ; 95 \% \mathrm{CI}$ : $1.1-2.7$; $\mathrm{p}<0.05)$ compared with the unemployed subjects. Significantly higher probability of cessation was among men $(\mathrm{OR}=5.6 ; 95 \% \mathrm{CI}: 3.8-8.1 ; \mathrm{p}<0.0001)$ and women $(\mathrm{OR}=4.4 ; 95 \% \mathrm{CI}: 2.7-7.1 ; \mathrm{p}<0.0001)$ who were aware of negative health consequences compared to those not aware., Being religious but not practicing was negatively correlated with successful smoking cessation among 
males $(\mathrm{p}<0.05)$. Religiosity was not associated with cessation among females. Age of onset smoking and place of residence did not influence smoking rates in both genders.

\section{Discussion}

This study demonstrates the association of long term cessation with socio-demographic predictors among a representative sample of Poles. This association remained after adjustment of other important variables. Several previous studies conducted with other populations have demonstrated similar associations $[3,7,9,12]$. Direct comparisons of GATS results with other studies are challenging due to diverse study designs, country profiles, different tobacco control policies among countries and time of conducting studies. Nonetheless, GATS identified that older age strongly predicted cessation, which is consistent with other studies $[10,26,27]$. The most common interpretation of this association is that with increasing age of subjects, the health worsens and increases the prevalence of symptoms caused by tobacco related diseases [7,28]. The study of Sieminska et al. showed that poor health motivates people to quit in order to reduce negative health effects of tobacco use, and many smokers are not successful in quitting before the manifestation of a severe disease [16]. Other researchers have reported patients quitting when they learned that they had a cardiovascular disease [11]. The more severe the condition, the greater the like hood of giving up smoking [11]. In fact, health concern is the most often revealed in the literature containing reasons for quitting tobacco consumption [26,28-30].

However, from a public health point of view, it would be better to encourage smokers to give up smoking before serious smoking-related health problems arise [28]. Although GATS did not assess the health status of respondents at the time of study completion, former smokers mentioned concerns about health hazard of smoking and price increase of cigarettes as the most important reasons for quitting. In the study conducted in Poland by Sieminska et al., similarly to GATS the most important reason for quitting smoking was general health concern (57\%). Other reasons were personal health problems (32\%) and social reasons (32\%). But we cannot compare those results directly because of differences in questionnaires that were applied in both studies.

Of notable interest, the implementation of public smoking bans was not cited by participants as a reason for wanting to quit smoking. Smoking ban in public places main focus is to protect nonsmokers from exposure to environmental tobacco smoke and cessation is the second aim. Nevertheless, implementing this strategy also increases quitting among smokers [4]. On the other hand, in Poland second hand smoke policies did not work appropriately. This can be explained by the fact that in Poland, total smoking bans do not cover all public places. There are numerous exceptions including bars, restaurants and worksites where smoking rooms are allowed. Furthermore, this policy can be ineffective as a tool to increase cessation rates due to poor enforcement [31]. Another interesting finding is that while high costs of cigarettes was pointed out as a second the most important reason for smoking cessation among all former smokers, it appeared to be a weaker motivator to quit for unemployed male respondents compared to the employed (Table 2). It can happen that after price increase economically disadvantaged smokers switch from manufactured cigarettes to hand-rolled or less expensive brands or buy illegal products however not give up smoking. Nonetheless, many smokers continue the habit even in spite of smoking-associated increase of socioeconomic inequalities, because disadvantaged smokers are not motivated to quit, and rather spend more money on tobacco, less to other goods what deepens deprivation. It suggests that aside fiscal policies, other policies should be used to increase cessation among lower socio-economic groups.

Our findings which show that the probability of successfully quitting smoking in employed men was markedly higher compared with unemployed men is in accord with previous evidence $[8,26,32]$. Positive association between success in quitting and socioeconomic resources is well established [12,33,34]. Possible explanations for the lack of the association of quitting smoking with employment among women in Poland, is the low participation of females in the labor market, and the traditional more involvement of women in household keeping, raising children and dependency on partner's wages [21]. It appears that this indicator does not adequately reflect women's social classes and economic positions. Similarly, association of employment with prevalence of current smoking was not found among women in Poland [21]. Moreover, we take these results with caution because one's employment status may change over the life span, but due to cross-sectional study design we can observe only one point of the time.

Another important factor increasing quit rates is increasing levels of education. Factors that may potentially contribute to inequalities in quit rates between respondents with higher and lower levels of education may include general knowledge about health, attitudes and social norms. People with lower levels of education may have less consideration or awareness of health risks of smoking and environmental tobacco smoke [21]. GATS showed a very strong correlation between educational level and successful cessation. This correlation is consistent with other findings $[3,7,20,32,35,36]$. Schaap et al., in 
the study of effects of nationwide tobacco control policies on smoking cessation in high and less educated groups in 18 European countries, noted that smokers with higher education were more likely to have quit smoking than smokers with lower education in all agesex groups in all countries [37]. Additionally, this study showed that countries with more developed tobacco control policies have higher quit ratios than countries with less developed tobacco control policies. Several tobacco control measures were introduced in Poland during the past decades including ban on cigarette advertising, taxation of tobacco, partial ban of smoking in public places or text of health warnings on packs of cigarettes [6,31]. However anti-tobacco policies are still not comprehensive in our country and there is a ground for further improvement including implementation of pictorial health warnings, media campaigns or $100 \%$ smoking ban in public places [31].

Another factor that we assessed in our study was potential correlation between successful cessation tobacco use and religiosity. We found that being religious did not influence cessation rates in female and male religious (but not practicing) respondents, and they were less likely to quit over a year period than the nonreligious ones. Poland is mostly a Catholic country and the abstinence from substance abuse is one of the principles of the church. On the other hand, religiosity is a very sensitive issue and maybe some respondents preferred to answer that they are religious but not practicing than to state that they are not religious. We can only speculate that they decided to choose more socially acceptable answers which influenced our observation. There is no clear explanation for this finding and we do not have other nationally representative statistics to compare with the GATS results. Unfortunately, this aspect remains unexplored and again more in depth studies are needed to investigate this association in our country. Nevertheless, it is worth addressing that according to some authors religion may play a part in health beliefs and behaviors such as tobacco use [38]. Reports suggest that religiosity in different faiths is associated with less use of tobacco [38,39]. Existing studies focus on influence of many different religions; for example Kabat et al. set that Jews had significantly higher quit rates compared to non-Jews [7]. However some authors suggest that members of the same community, even if they adhere to different faiths, seem to have similar patterns of tobacco use. Maziak et al. have previously discussed that where differences occurred, it is not clear whether this is due to religion or to broader social differences of which religion is only one [40].

Although we did not find an association between age of smoking initiation and quitting in the multivariate analysis in other studies have shown that, older age of smoking uptake was correlated with increased cessation rates $[10,32]$. Breslau et al. reported that likelihood of smoking cessation was greater in smokers who had begun cigarette smoking after age 13 than in those who had begun earlier. Compared with smokers in the earliest initiation group, smokers who began at 14 to 16 years were 1.6 times more likely to quit, and those who began at age 17 or later were twice as likely to quit [32]. Similarly, in the study by Khuder et al., men who started smoking before 16 years of age had an odds ratio of 2.1 (95\% confidence interval: 1.4-3.0) for not quitting smoking compared to those who started at a later age [41]. Higher quit rates among those who started smoking on regular basis at a later age may be due to the fact that these groups are probably less habituated and can quit more easily. Evidence shows that nicotine dependent smokers have more difficulty quitting and are therefore less likely to quit successfully than non-dependent smokers [32]. In the study of Breslau et al., smokers with nicotine dependence were $40 \%$ less likely to quit than smokers who were not dependent [32]. According to a recent study by Marquese-Valdez at al., difficulty to quit increased with increasing nicotine dependence and the number of previous quitting attempts [28]. In the population of International Tobacco Control (ITC) Four Country Study, Hyland et al. also found [10] that lower levels of nicotine dependence was the main factor that predicted future cessation among those who made a quit attempt. Existing data suggests that programs that delay smoking initiation might have significant value even if they do not lead to fully preventing the uptake of smoking [32]. It is suggested that delaying smoking initiation among adolescents could in the long run reduce the rate of smoking through increasing the potential for successful cessation [32].

It is remarkable and relevant to health policy planners and tobacco control professionals that high numbers of current smokers were not discussed with and advised to quit. Also, a very small number of those who made a quit attempt used any aid. Aveyard et al. has stressed that brief interventions - doctors advising patients to stop smoking- is the simplest approach that can increase smoking cessation [42]. This relatively easy to accomplish, non-time-consuming procedure, has been found to be effective [43]. According to Stead et al. most patients who receive such advice will not act on it, and most people who act on it will not succeed at the first attempt [43]. Regardless, this intervention is of vital importance to public health and it is important to maximize its effectiveness. The most common intervention doctors make is to advise cessation (because it will prevent ill health), but offering support for smoking cessation (such as medication or behavioral support) enhances the rate at which people attempt to stop smoking $[4,42,44]$. In Poland, nicotine replacement 
medications are available over the counter while Varenicline and Buproprion are available on prescription [6]. None of these medications are reimbursed even partly by the NHF and, therefore, many smokers who want to quit cannot afford these treatments. National Health Fund (NHF) reimburses just smoking counseling. In addition, funds assured for this activity are very limited whereas financial incentives are seen as an approach to encourage more systematic use of smoking cessation interventions by healthcare professionals [45]. Financial incentives appear to improve recording of smoking status, and increase the provision of cessation advice and referrals to stop smoking services [45]. The anti-nicotine intervention should be an essential component of the primary medical services contracted by the National Health Fund. Moreover healthcare professionals need to be adequately prepared and paid for providing relevant antinicotine interventions [6]. The reach of interventions needs to be broadened to increase quit rates in Poland.

\section{Study limitations}

GATS provided nationally representative data based on a high number of respondents including current and former smokers. However the well-known potential limitation is using self-reported techniques to obtain data, but this issue was discussed in previous papers and should not substantially influence the quality of the study [21,23]. Although GATS questionnaire included questions on duration of tobacco smoking and age of smoking onset, the nicotine dependence or number of cigarettes smoked per day that are considered important determinants of cessation were missing for long-term quitters. Similarly, data on aided or unaided quitting are not available for respondents maintaining cessation for one year or longer. Moreover, the information on number of quitting attempts and their duration needed for successful cessation were omitted. Data on annual household net income as well as marital status should also be taken into consideration in future surveys because these variables may contribute to quitting $[11,30]$. Moreover the cross-sectional nature of this study limits the ability to draw conclusions about the directionality of the findings. A different limitation of the GATS project is that all information was collected at the time of interview [7]. While some of the characteristics may not have changed over time, others such as employment status may have changed and we cannot check past circumstances. This limits our ability to conclude on some factors like employment status as a predictor of smoking cessation.

\section{Conclusions}

In contrast to more developed countries there is still the lack of steady tobacco surveillance system in Poland.
Thus we do not have nationally representative data produced on annual basis. Literature on predictors of tobacco smoking cessation in Poland is relatively undeveloped so far. To our knowledge, GATS is the first study assessing simultaneous impact of several sociodemographic indicators on successful cessation among Poles, and probably the first to consider religiosity in such analysis. GATS provided key policy implications. In spite of some limitations of GATS we have indicated several significant associations of long-term smoking cessation including older age, high education attainment, employment in men and awareness of smoking health consequences among both genders. These findings may give framework for tailoring effective antismoking measures addressing adults. Apart from improving the effectiveness of the cessation broadening reach of such services, which is essential, cessation programs also need to address younger age groups and less likely to quit groups of population. Moreover, interventions to raise awareness on smoking health risks and quitting benefits are fundamental to increase cessation potential among adult smokers. This study clearly shows that other aspects of tobacco control in Poland like smoke-free policies should be expanded in order to increase the quitting rates. However, still crucial to preventing tobacco related diseases and maintaining good health is to never start smoking. Thus future research is also needed to examine indicators that contribute to the initiation of smoking among Poles to increase comprehensiveness of anti-tobacco policies.

\section{Competing interests}

The authors declare that there are no conflicts of interest.

\section{Authors' contributions}

DK led the project, outlined the paper, discussed core ideas, and prepared the final manuscript. PK prepared the dataset, did the data analysis, TMD drafted the paper discussed core ideas and commented extensively on drafts. BU drafted the paper, and did the literature search. LBR commented on drafts. AF discussed core ideas and commented on drafts. All authors read and approved the final manuscript.

\section{Acknowledgements}

Financial support was provided by the Bloomberg Initiative to Reduce Tobacco Use, a program of Bloomberg Philanthropies. We would like to thank the representatives of the Global Adult Tobacco Survey Scientific Committee (Poland) including: Professor Witold Zatonski (Cancer Center and Institute of Oncology, Warsaw), Professor Boleslaw Samolinski (Medical University of Warsaw), Dr. Przemyslaw Bilinski (Chief Sanitary Inspector, Warsaw), and members of the Technical and Survey Staff Team (Krzysztof Przewoźniak, Jakub Łobaszewski, Magdalena Cedzyńska - Cancer Center and Institute of Oncology, Warsaw; Filip Raciborski - Medical University of Warsaw) as well as our Partners from the World Health

Organization (Dr. Lubna Bhatti, Dr. Sameer Pujari), Centers for Disease Control and Prevention (Dr. Samira Asma, Dr. Krishna Mohan Palipudi), CDC

Foundation, Johns Hopkins Bloomberg, School of Public Health and the RTI International for their involvement.

\section{Author details}

'Department of Preventive Medicine, Medical University of Łódź, Łódź, Poland. ${ }^{2}$ Faculty of Computer Science and Information Technology, West Pomeranian University of Technology in Szczecin, Szczecin, Poland. 
${ }^{3}$ Department of Work Physiology and Ergonomics, Nofer Institute of Occupational Medicine, Łódź, Poland. ${ }^{4}$ Public Health Faculty, Medical University of Łódź, Łódź, Poland. ${ }^{5}$ Department of Public Policy, University of Massachusetts, Boston, USA. ${ }^{6}$ Department of Nutrition in Digestive Tract Diseases, Medical University of Łódź, Łódź, Poland. ${ }^{7}$ Department of Biopharmacy, Medical University of Łódź, Łódź, Poland.

Received: 11 August 2012 Accepted: 17 November 2012 Published: 22 November 2012

\section{References}

1. World Health Organization (WHO): WHO global report: mortality attributable to tobacco. Geneva: WHO; 2012

2. Edwards $R: A B C$ of smoking cessation. The problem of tobacco smoking BMJ 2004, 328(7433):217-219. doi:10.1136/bmj.328.7433.217.

3. Federico B, Costa G, Ricciardi W, Kunst AE: Educational inequalities in smoking cessation trends in Italy, 1982-2002. Tob Control 2009, 18:393398. doi:10.1136/tc.2008.029280

4. Zhu SH, Lee M, Zhuang YL, Gamst A, Wolfson T: Interventions to increase smoking cessation at the population level: How much progress has been made in the last two decades? Tob Control 2012, 21:110-118.

5. Shafey O, Eriksen M, Ross H, Mackay J: Tobacco atlas. Atlanta: American Cancer Society; 2009

6. World Health Organization (WHO): The current status of the tobacco epidemic in Poland. Copenhagen: WHO; 2009.

7. Kabat G, Wynder E: Determinants of quitting smoking. Am J Public Health 1987, 77:1301-1305.

8. Cengelli S, O'Loughlin J, Lauzon B, Cornuz J: A systematic review of longitudinal population-based studies on the predictors of smoking cessation in adolescent and young adult smokers. Tob Control 2012, 21(3):355-362. Epub 2011 Aug 16

9. Kim YN, Cho YG, Kim CH, Kang JH, Park HA, Kim KW, Hur YI, Lee SH, Na YM, Park NY: Socioeconomic indicators associated with initiation and cessation of smoking among women in Seoul. Korean J Fam Med 2012, 33:1-8.

10. Hyland A, Borland R, Li Q, Yong H-H, McNeill A, Fong GT, O'Connor RJ, Cummings KM: Individual-level predictors of cessation behaviours among participants in the international tobacco control (ITC) four country survey. Tob Control 2006, 15:iii83-iii94. doi:10.1136/tc.2005.013516.

11. Rice VH, Templin T, Fox DH, Jarosz P, Mullin M, Seiggreen M, Lepczyk M: Social context variables as predictors of smoking cessation. Tob Control 1996, 5(4):280-285.

12. Nagelhout GE, de Korte-de Boer D, Kunst AE, van der Meer RM, de Vries $H$, van Gelder BM, Willemsen MC: Trends in socioeconomic inequalities in smoking prevalence, consumption, initiation, and cessation between 2001 and 2008 in the Netherlands. Findings from a national population survey. BMC Public Health 2012, 12:303. doi:10.1186/1471-2458-12-303.

13. Donzé J, Ruffieux C, Cornuz J: Determinants of smoking and cessation in older women. Age Ageing 2007, 36(1):53-57. doi:10.1093/ageing/afl120.

14. Dawood N, Vaccarino V, Reid KJ, Spertus JA, Hamid N, Parashar S: PREMIER Registry Investigators. Predictors of smoking cessation after a myocardial infarction: the role of institutional smoking cessation programs in improving success. Arch Intern Med 2008, 13;168(18):1961-1967.

15. Schnoll RA, Martinez E, Langer C, Miyamoto C, Leone F: Predictors of smoking cessation among cancer patients enrolled in a smoking cessation program. Acta Oncol 2011, 50(5):678-684. Epub 2011 May 2.

16. Sieminska A, Buczkowski K, Jassem E, Lewandowska K, Ucinska R, Chelminska M: Patterns of motivations and ways of quitting smoking among Polish smokers: a questionnaire study. BMC Public Health 2008, 8(4):274.

17. Hiscock $R$, Judge $K$, Bauld $L$ : Social inequalities in quitting smoking: what factors mediate the relationship between socioeconomic position and smoking cessation? J Public Health (Oxf) 2011, 33(1):39-47. Epub 2010 Dec 22

18. Kendzor DE, Businelle MS, Costello TJ, Castro Y, Reitzel LR, Cofta-Woerpel LM Li Y, Mazas CA, Vidrine Jl, Cinciripini PM, Greisinger AJ, Wetter DW: Financial strain and smoking cessation among racially/ethnically diverse smokers. Am J Public Health 2010, 100(4):702-706. Epub 2010 Feb 18.

19. Sachs-Ericsson N, Schmidt NB, Zvolensky MJ, Mitchell M, Collins N, Blazer DG: Smoking cessation behavior in older adults by race and gender: The role of health problems and psychological distress. Nicotine Tob Res 2009, 11(4):433-443. first published online January 1, 2009

20. Reid J, Hammond D, Boudreau C, Fong GT, Siahpush M: Socioeconomic disparities in quit intentions, quit attempts, and smoking abstinence among smokers in four western countries: findings from the international tobacco control four country survey. Nicotine Tob Res 2010 12(suppl 1):S20-S33. doi:10.1093/ntr/ntq051.

21. Kaleta D, Makowiec-Dabrowska T, Dziankowska-Zaborszczyk E, Fronczak A: Prevalence and socio-demographic correlates of daily cigarette smoking in Poland: results from the global adult tobacco survey (2009-2010). IJOMEH 2012, 25(2):126.

22. Kaleta D, Kozieł A, Miśkiewicz P: Global adult tobacco survey in Poland the aim and current experiences. Med Pr 2009, 60(3):197-200 [in Polish].

23. Kaleta D, Makowiec-Dąbrowska T, Dziankowska-Zaborszczyk E, Fronczak A: Determinants of heavy smoking: Results from the global adult tobacco survey in Poland (2009-2010). IJOMEH 2012, 25(1):66.

24. Ministry of Health of Poland: Global adult tobacco survey. Poland 2009-2010. Warsaw: Ministry of Health; 2010. citation date: 27 July 2012]. Available from URL: http://www.mz.gov.pl/wwwfiles/ma_struktura/docs/sondaz_tyt_15112010. pdf [in Polish].

25. Shumaker SA, Grunberg NE: Proceedings of the national working conference on smoking relapse. July 24-26, 1985, Bethesda, Maryland. Health Psychol 1986, 5(Suppl):1-99.

26. Halpern M, Warner K: Motivations for smoking cessation: a comparison of successful quitters and failures. J Subst Abuse 1993, 5:247-256.

27. Fernández E, Carné J, Schiaffino A, Borràs J, Saltó E, Tresserras R, Rajmil L, Villalbí J, Segura A: Determinants of quitting smoking in Catalonia, Spain. Gac Sanit 1999, 13(5):353-360.

28. Marques-Vidal P, Melich-Cerveira J, Paccaud F, Waeber G, Vollenweider P, Cornuz J: Prevalence and factors associated with difficulty and intention to quit smoking in Switzerland. BMC Public Health 2011, 11:227. Apr 13.

29. Bednarek M, Gorecka D, Wielgomas J, Czajkowska-Malinowska M, Regula J, Mieszko-Filipczyk G, Jasionowicz M, Bijata-Bronisz R, Lempicka-Jastrzebska M, Czajkowski M, Przybylski G, Zielinski J: Smokers with airway obstruction are more likely to quit smoking. Thorax 2006, 10:869-873.

30. Augustson EM, Wanke KL, Rogers S, Bergen AW, Chatterjee N, Synder K, Albanes D, Taylor PR, Caporaso NE: Predictors of sustained smoking cessation: a prospective analysis of chronic smokers from the alphatocopherol Beta-carotene cancer prevention study. Am J Public Health 2008, 98:549-555.

31. World Health Organization (WHO): WHO report on the global tobacco epidemic, 2011: warning about the dangers of tobacco. Geneva: WHO; 2011.

32. Breslau N, Peterson EL: Smoking cessation in young adults: age at initiation of cigarette smoking and other suspected influences. Am J Public Health 1996, 86(2):214-220.

33. Lee CW, Kahende J: Factors associated with successful smoking cessation in the United States, 2000. Am J Public Health 2007, 97(8):1503-1509. Epub 2007 Jun 28.

34. Marti J: Successful smoking cessation and duration of abstinence - an analysis of socioeconomic determinants. Int J Environ Res Public Health 2010, 7(7):2789-2799. doi:10.3390/ijerph7072789. Published online 2010 June 30

35. Schaap MM, Kunst AE: Monitoring of socio-economic inequalities in smoking: learning from the experiences of recent scientific studies. Public Health 2009, 123(2):103-109. Epub 2009 Jan 14.

36. Osler M, Prescott E, Godtredsen N, Hein HO, Schnohr P: Gender and determinants of smoking cessation: a longitudinal study. Prev Med 1999, 29:57-62

37. Schaap MM, Kunst AE, Leinsalu M, Regidor E, Ekholm O, Dzurova D, Helmert U, Klumbiene J, Santana P, Mackenbach JP: Effect of nationwide tobacco control policies on smoking cessation in high and low educated groups in 18 European countries. Tob Control 2008, 17(4):248-255. Epub 2008 May 15.

38. Jabbour S, Fouad F: Religion-based tobacco control interventions: how should WHO proceed? Bull World Health Organ 2004, 82(12):923-927. ISSN 0042-9686.

39. Whooley MA, Boyd AL, Gardin JM, Williams DR: Religious involvement and cigarette smoking in young adults: the CARDIA study (coronary artery risk development in young adults study). Arch Intern Med 2002, 162(14):1604-1610. Jul 22

40. Maziak W, Asfar T, Mzayek F: Socio-demographic determinants of smoking among low-income women in Aleppo, Syria. Int J Tuberc Lung Dis 2001, 5:307-312. 
41. Khuder S, Dayal H, Mutgi A: Age at smoking onset and its effect on smoking cessation. Addict Behav 1999, 24(5):673-677.

42. Aveyard P, Raw M: Improving smoking cessation approaches at the individual level. Tob Control 2012, 21:252-257. doi:10.1136/tobaccocontrol2011-050348.

43. Stead LF, Bergson G, Lancaster T: Physician advice for smoking cessation. Cochrane Database Syst Rev 2008, 2008(4):CD000165.

44. Perkins KA, Scott J: Sex differences in long-term smoking cessation rates due to nicotine patch. Nicotine Tob Res 2008, 10:1245-1250.

45. Hamilton FL, Greaves F, Majeed A, Millett C: Effectiveness of providing financial incentives to healthcare professionals for smoking cessation activities: systematic review. Tob Control 2011, doi:10.1136/tobaccocontrol-2011-050048.

doi:10.1186/1471-2458-12-1020

Cite this article as: Kaleta et al:: Predictors of long-term smoking

cessation: results from the global adult tobacco survey in Poland (20092010). BMC Public Health 2012 12:1020.

\section{Submit your next manuscript to BioMed Central and take full advantage of:}

- Convenient online submission

- Thorough peer review

- No space constraints or color figure charges

- Immediate publication on acceptance

- Inclusion in PubMed, CAS, Scopus and Google Scholar

- Research which is freely available for redistribution 